\title{
The effect of corporate social responsibility and corpo- rate governance on company's performance
}

\author{
Asep Alipudin ${ }^{1 *}$, Harry Suharman ${ }^{2}$ \\ 1, 2 University of Padjadjaran, Sumedang, Indonesia
}

\author{
Keywords \\ Corporate social responsibility \\ Corporate governance \\ Company's performance \\ Received: 5 December 2018 \\ Accepted: 3 January 2019 \\ Published: 20 February 2019
}

\begin{abstract}
This research aims to determine the effect of corporate social responsibility and corporate governance on companies performance on BUMN (state-owned enterprises), which are registered in the Indonesian Stock Exchange from 2012 until 2017. The number of the sample was 14 companies. The phenomenon that occurred was that the performance of state-owned enterprises with Return on Assets (ROA) indicator was more decreasing from 2012 until 2016. The company pays attention to the business interests, but the social responsibility needs to be paid attention to create the added value. Many things must be solved in State-Own Enterprises, especially in corporate governance. Results show that Good Corporate Governance (GCG) does not affect ROA where CSR, the Board of Directors, the Board of Commissioners, and the Audit Committee significantly affect ROA in state-owned enterprises registered on the IDX. These findings imply that the implementation of GCG is very necessary to build public trust in value creation. Therefore, companies need to implement GCG principles and practices in each company unit.
\end{abstract}

(C) 2019 The Author(s). Published by TAF Publishing.

\section{INTRODUCTION}

At present, the rapid development of the concept of Corporate Social Responsibility (CSR) is where companies participate in and empathy with various environmental and social issues around the company (Bhardwaj, Chatterjee, Demir, \& Turut, 2018). From the existence of companies whose activities in addition to providing many benefits but also a lot of negative impacts from company activities in the middle of the environment. Making companies no longer only pay attention to company financial records (single bottom line), but must pay attention to various aspects including financial aspects (profit), social aspects (people), and environmental aspects (planet), commonly called the triple bottom line (Purnamasari \& Fitdiarini, 2016; Sari, 2012).

The company manager will reveal social information in order to enhance the positive image (brand) of stakeholders that can be felt, and help in sustainable development even though he must sacrifice resources for these activities (Gray, Owen, \& Maunders, 1988; Hang, 2015). CSR is increasingly becoming a vital component of modern corporate culture due to rising expectations from stakeholders in light of a growing global awareness of the need for strong corporate governance, environmental protection and social care (Hou, 2019; Ketsiri \& Pajongwong, 2016).

In addition, companies must also pay attention to corporate governance because it is something that is considered important as happened in the government of the country. The implementation of Good Corporate Governance (GCG) at this time is no longer just an obligation, but has become a necessity for every company and organization. When firms had larger boards, they performed better. Larger boards may allow more leeway for professional managers to exercise their judgment, helping create more space for fresh insights (Ciftci, Tatoglu, Wood, Demirbag, \& Zaim, 2019).

The implementation of GCG is very necessary to build public trust. Therefore it is necessary to understand the principles and practices of GCG in each company. CG is now shifting from its conventional attention on agency issues

${ }^{*}$ corresponding author: Asep Alipudin

†email: asep.alipudin@unpak.ac.id 
by focusing more on matters related to social and business ethics, accountability to shareholders, transparency of financial statements, and disclosures. Board of Directors and management of an organization obviously study numerous elements when formulating policies to improve the community welfare that is constant with the directives of good governance (Aslam, Ahmad, Amin, Usman, \& Arif, 2018; Yoo, Lee, \& Lee, 2016).

The above will have an impact on financial performance, which is closely related to the timeliness of financial statement submission which is part of good corporate governance in GCG. Effendi (2009) GCG is a system of internal control of a company that has the main goal of managing significant risks in order to fulfill its business objectives through safeguarding company assets and increasing shareholder investment value in the long run.

Assessment of the company's financial performance is an activity that is very important because based on these assessments can be used as a measure of the company's success over a certain period of time. The better the company's financial performance, the company can be said to be more successful (Andriana \& Panggabean, 2016; Wartika, Surendro, Satramihardja, \& Supriana, 2015).
The role of State Owned Enterprises in the national economy of the Republic of Indonesia is urgently needed to keep the country's economy stable. The State Owned Enterprises also have strategic role as as a public service provider, balancing large private company, and contributing to the development of small businesses/cooperatives. Now, Indonesia State Owned Enterprises has 118 companies, which is divided into 13 sectors, such as sectors of manufacturing, supply and beverage industry, information and telecommunication, financial services and insurance, construction, mining, agriculture, etc. Those sectors are divided into two kinds of State Owned Enterprises, there are Limited Liabilities Company and Public Company. Limited Liabilities Company is the company that the capital is in the form of shares and some of the capital is owned by the State to make profit as the purpose. Public company is the State Company which is established for the purpose of serving the interests of the community.

Based on the fact that has been obatained, the number of State Owned Enterprises that have been Go Public in Indonesia Stock Exchange is 20 companies. From the 20 companies, the company's performance can be seen by ROA which is displayed on this following chart.

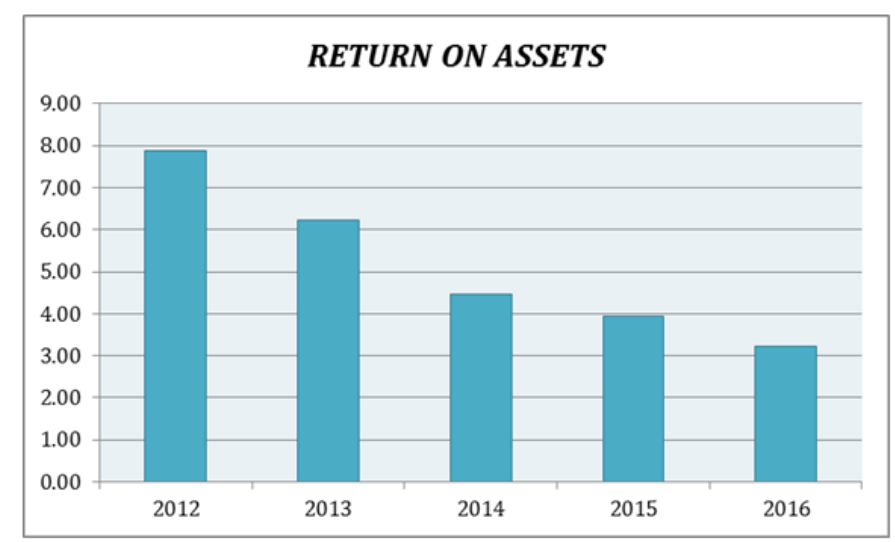

FIGURE 1. State Owned Enterprises (SOEs) with ROA indicator in 2012-2016 Source: (World Bank, 2017)

Based on the Figure 1 above, it can be seen that State Owned Enterprises' performance which is registered in Indonesia Stock Exchange with ROA indicator was more decreasing from 2012 until 2016. In 2012 until 2013, each ROA were $7.89 \%$ and $6.22 \%$. While in 2014 the average of State Owned Enterprises' ROA reached 3.23\%, in 2015, the number had decreased into $2.70 \%$ and had got decreasing again into $2.62 \%$ in 2016.

The State Owned Enterprises have the ability to reach the better performance and have the consistent growth rate. It is based on the big assest that they have. The power of as- sets owned is the initial capital to be able in reaching optimal performance if the assets owned are managed properly. Accounting-based performance measurement which is commonly used are ROA (Kotler \& Lee, 2008), Return on Equity (ROE) (Basyith, 2016) and earning per share Menaje (Marfa, Niguidula, \& Enriquez, 2017; Menaje Jr, 2012) test the effect of financial variable, Earning Per Share (EPS) and ROA on the price of the Philippine company's public shares. The result of the research shows there is a strong positive relation between EPS and share price, while there is a weak negative relation between ROA and share price. 
The performance of State Owned Enterprises is not optimal yet, it is assumed that it has not paid attention to CSR. The stakeholders must get attention to social, economic, and environmental services. The company does not only care about business interests but social responsibility must be paid attention to create the added value.

It is better that company has public concern, it is because there are many problems that have arisen such as pollution, waste disposal, depletion of resources, security and product quality, as well as the rights and status of workers which has begun to be criticized by several parties. Those problems should have been company's priority in developing CSR program (Reverte, 2009). The responsibility is included the prevention of negative effect of the company to other parties and environment also increasing the community including the employees, suppliers, customers and the environment around the company (Drucker, 1997).

Aside from CSR, the performance of State Owned Enterprises is not optimal yet, it is also assumed because of the weakness and lack of implementation of the principles of GCG in all State Owned Enterprises which affected on company's performance (Clark \& Sanders, 2011).

The purpose of good corporate governance is to reach the organization plan by controlling the organization operation system, managing relationships between the stakeholders, determining direction, and work achievement (Ratih \& Setyarini, 2014). The Government has role in implementing good corporate governance. Generally, government is considered having good corporate governance, will gain the trust from the stakeholders and will result in good business and company's culture (Menaje Jr, 2012).

Every company has the same goal in general, it is to reach the good performance, can grow and develop also last in running business. The goal will be achieved if between the owners of the company or the stakeholders and the management as the company's manager have the same goal. But, in fact the managers have their own private goals which is competed with the goal to maximize the stakeholders' wealth. This problem creates the potential conflict of interests which is called Agency theory (Hema, 2012). Research that takes the context of the effect of corporate social responsibility on company's performance has been done previously by several previous studies. Research by Ridho (2016); Sun (2012) states in his research that corporate social responsibility influences company performance. Whereas previous research on the effect of corporate governance on company performance has also been carried out by previous researchers. There are differences in the final results from several previous studies on the effect of corporate governance on company performance. Research by Herdjiono and Sari (2017) states that the size of directors affects the performance of the company, while the size of audit committees, institutional ownership, and managerial ownership does not affect the company's performance. While Basyith (2016) Makki and Lodhi (2014) gave results that GCG does not affect the company's performance.

The difference in the final conclusions from previous studies is one of the things that are considered by researchers to re-examine the effect of corporate social responsibility and good corporate governance on company performance by using state-owned companies listed on the Indonesia Stock Exchange. This topic is important to study because in the current economic development, the development of CSR and GCG in companies, state-owned companies must always maintain their performance in line with the demands of the government and society.

The phenomenon of company's performance requires the implementation of corporate social responsibility and good corporate governance. The purpose of this study is to determine the effect of corporate social responsibility and corporate governance on company's performance.

\section{LITERATURE REVIEW}

\section{Grand Theory}

The company's legitimacy in the eyes of stakeholders is a significant factor to support the image and reputation of the company in the eyes of stakeholders (Hadi, 2011). Thus, the disclosure of CSR information is a long-term investment, and has benefits in improving image and legitimacy, so that it can be used as a basis for the construction of the company's strategy (Sari, 2012).

Apart from that, in agency theory, shareholders (principal) are the owners of the company and have ownership rights to profits generated by the company. Meanwhile, managers are agents (agents) who act in the interests of company owners (Sari, 2012). Thus, if management does not make profit maximization, the market will make corrections to company management, for example by changing managers (Dewanta, 2011).

\section{Corporate Social Responsibility}

Social responsibility is stated in a report called Sustainability Reporting. Sustainability Reporting is a report on economic, environmental and social policies, which is the influence and organizational performance and products in the context of sustainable development (Kotler \& Lee, 2008). Sustainability Reporting is a report that shows the social accountability of the company. Priantana and Yustian (2011) 
Sustainability Reporting is an economic, environmental and social policy, where the influence and performance of the organization and its products are in accordance with the relationship of sustainable development.

CSR measurement in this study involves the Global Reporting Initiative (GRI), which is an organization that has pioneered world development, using the most sustainable reports and supported to make improvements and implementations.

Three main operating factors in relation to the environment and humans (People, Profit, and Planet), social responsibility programs are important to be implemented by companies because company profits depend on society and the environment. Companies cannot simply ignore the role of stakeholders (consumers, workers, society, government, and business partners) and shareholders by purely pursuing profit (Elkington, 1998).

According to Menaje Jr (2012) The World Bank has provided a category of government roles in supporting CSR in five categories. Menaje Jr (2012) describe the role of the public sector that can be adopted by the government on CSR issues, namely mandatory (role of legislation), facilitating (e.g., guidance on CSR report content), partnering (multi-stakeholder strengthening process), and endorsing ( Publication and awarding). O'Rouke (2004) provides a more detailed explanation of the categories of government roles above. First, the role of mandating is when the government legally gives a mandate through laws or government regulations. So that the government can carry out supervision in terms of CSR reporting both evaluation of reports and cross checking of the contents of the report. The second is facilitating when the government provides a reference or guidelines in implementing and reporting CSR and disseminating CSR information. Third is partnering in which the government is involved in the process of promoting multi-stakeholder cooperation initiatives or cooperation with each company. In other words the government can be a facilitator of dialogue between stakeholders. Fourth is the endorsing role in reporting CSR programs through a positive effort in the transparency framework as an example of CSR awards.

CSR relates to building strong relationships between companies and stakeholders through transparency information and contributions to society and the environment. Brickley and Zimmerman (2010) Corporate social responsibility as a commitment to improve community welfare through business discretionary practices and contribution of company resources. CSR is a process operated by companies to take action on social and environmental management in all products and services that involve all the stakeholders (Herdjiono \& Sari, 2017).

The CSR measurement instrument that will be used in this study refers to (Global Reporting Initiative, 2013). GRI is an organization-based network that has pioneered the development of the world, using the most continuous reports and is committed to continuous improvement and application throughout the world. GRI consists of 3 focus of disclosure, namely as follows:

1. Economy

2. Environment

3. Social

H1: Corporate Social Responsibility had a significant effect on Company's Performance.

\section{Corporate Governance}

To safeguard the value of the life of the Company's organization in relation to various stakeholders, which includes shareholders, management, employees, their government and agencies, creditors, suppliers, consumers and the public must pay attention to governance. Governance is a tool to reduce agency costs that create conflict between managers and shareholders. According to Effendi (2009) GCG is a system of internal control of a company that has the main goal of managing significant risks in order to fulfill its business objectives through securing company assets and increasing shareholder investment value in the long run.

There are several key factors in implementing good corporate governance. These factors are classified into internal and external factors. Examples of internal factors are companies that have good risk control management. External factors, namely the support of the public sector/government institutions in the implementation of GCG.

According to the National Committee on Governance Policy (Reverte, 2009), the success of implementingGCG in companies is determined by several factors, including:

1. Commitments from company organs based on good faith to implement GCG systematically, consistently and continuously.

2. Creation of a system of implementing GCG at all levels and deseminating and disseminating systematically, consistently and continuously by including all parties within the company and other stakeholders.

3. Adjustment of company regulations and policies with a system of implementing GCG.

4. Implementation of the duties and responsibilities of all company lines that refer to the code of conduct.

5. Support from stakeholders.

6. Evaluation of the implementation of GCG which is con- 
ducted periodically by the company itself or by appointing other competent and independent parties.

Indonesian companies must actually be responsible for implementing the Corporate Governance standards that have been implemented. However, in its implementation it is still low, they still have not implemented the principles of governance to the maximum due to several provisions that oppose and there are those who oppose those who consider these principles as part of company requirements.

In principle, corporate governance is a system which the company's business is directed and controlled. The government determines the distribution of rights and responsibilities among companies, such as boards, managers, and others as stakeholders (Karwowski, 2014). Corporate governance broadly as a system of laws, regulations, institutions, markets, contracts, and company policies and procedures (such as internal control systems, policies, and budgets) that direct and influence the actions of top-level decision makers in company (shareholders, board of directors, and executives). Baysinger and Butler (1985) furthermore, corporate governance as a whole set of legal, cultural and institutional arrangements that determine what can be done by a public company, who controls the company, how the control is carried out, and how the risks and results of the activities carried out it is allocated. Chakravarthy (1986) GCG as a collection of customary processes, policies, laws and institutions that influence the company by conducting direction, administration, and control (Yusoff, Jamal, \& Darus, 2016). Corporate governance took 5 (five) dimensions, namely (Andriana \& Panggabean, 2016; Yusoff et al., 2016).

\section{Board of Commissioners}

The board of commissioners is the organ of the Company in charge of carrying out supervision in general and/or specifically in accordance with the articles of association and advising the directors.

\section{Board of Directors}

The board of directors is a control centre in the company and this board has the responsibility for health and the company's long-term success.

3. Audit Committee

The audit committee is a group of people appointed by the board of commissioners, responsible for maintaining the auditor's independence from management.

\section{Institutional Ownership}

Institutional ownership is the total number of shares owned by the institution. The existence of institutional ownership can monitor their increase in investment professionally so that the level of control over management is very high, which in turn can reduce the potential for fraud.

\section{Managerial Ownership}

Managerial ownership is a shareholder of the company where shares are owned by the management of the company who actively participates in the decision making of the company (Director and Commissioner). This is measured by the percentage of shares owned by management.

H2: GCG had a significant effect on Company's Performance.

\section{Company's Performance}

The meaning of the performance is the level of achievement or tangible results which is achieved sometimes used to obtain a positive result (Cho \& Pucik, 2005). Performance is also defined as the success of personnel in realizing strategic goals in four perspectives: financial, customer, process, and learning and growth. Jensen and Meckling (1976) Superior financial performance is a way to satisfy investors (Carroll, 1991) and can be represented by profitability, growth and market value (Carroll, 1979; Priantana \& Yustian, 2011). The company performance is a term to show the operational success of a company (Kiel \& Nicholson, 2003).

The company's performance can be very beneficial for stakeholders, such as investors, analysis, financial consultants, government and management itself. They see companies as a basis for making their managerial decisions. One measure that can be used to assess company performance is financial statements. Company performance or company quality can be calculated or analyzed from the components in the company's financial statements. From the financial statements, you can find out the finances and results that have been approved by the company for a certain period. Measurable performance of program implementation will encourage achievement. Continuous measurement of achievements provides feedback for continuous improvement efforts and achieving goals in the future. Performance assessments are carried out to suppress undue behavior, to stimulate and enforce desirable behavior through feedback on the performance results in time, and rewards. Organizational performance has many dimensions, such as long-term performance, short-term performance, financial performance, non-financial performance and relationshipbuilding performance (Borhan, Naina Mohamed, \& Azmi, 2014).

Several financial ratios are often used to measure company's performance (Borhan et al., 2014).

1. Liquidity Ratio

The liquidity ratio is a ratio that describes the company's ability to solve its short-term liabilities. 


\section{Turnover Ratio}

Turnover ratio is a ratio that describes the activities carried out by a company in carrying out its operations both in sales, purchases or other activities.

3. Profitability Ratio

Profitability ratios are ratios that describe a company's ability to make a profit through all capabilities, and available sources such as sales activities, cash, and capital of the number of employees and so on.

4. Leverage Ratio

Leverage ratio is a ratio that describes the company's ability to pay its long-term liabilities or liabilities if the company is liquidated.

To measure the company's operating performance, it is usually used a profitability ratio. Profitability ratio measures the ability of a company to make finance at a certain level of sales, assets, share capital. The ratio that is often used is ROA. ROA can reflect business profits and company efficiency in the utilization of total assets in the company. This ratio represents the profitability ratio, which measures the company's ability to make profits by using the total assets of the company. The higher the ROA value, the more efficient the company in using its assets, will make profits for the company.

Return On Assets (ROA) is part of profitability ratio analysis. ROA is a ratio between net income which is inversely proportional to the overall assets to generate profits. This ratio shows how much the net profit obtained by the company is measured by the value of its assets.

ROA is a ratio between net income which is inversely proportional to the overall assets to generate profits. This ratio shows how much the net profit obtained by the company is measured by the value of its assets. Analysis of ROA or often translated in Indonesian as economic rentability measures the development of companies generating profits in the past. This analysis is then projected into the future to see the company's ability to generate profits in the future.

H3: Corporate Social Responsibility and GCG had a significant effect on Company's Performance.

\section{RESEARCH METHODOLOGY}

The type of research used is verification research on the influence of CSR and GCG on company's performance. This research is used as a research location, namely the Indonesia Stock Exchange (IDX). The research technique used is quantitative analysis statistics. The research technique used in the researcher to find out the relationship between the two variables is statistical analysis, namely by looking at the descriptive statistical table that shows the results of the mea- surement of the mean, standard deviation, minimum and maximum values of all variables.

\section{Variables}

1. Independent variables are types of variables that explain or influence other variables, this variable is also called the presumed cause variable of the dependent variable. The independent variable used is corporate social responsibility measured using indicators of Corporate Social Responsibility Discloser Index. CSDIj is a Corporate Social Responsibility Disclosre Index.

$$
\operatorname{CSRDI} j=\frac{\sum x i j}{n j}
$$

Notes:

CSRDIj : Corporate Social Responsibility Disclosure Index company $j$

$\mathrm{Nj}$ : Number of item for companyj

$\mathrm{Xij}$ : dummy variable: $1=$ if item I disclosed; $0=$ if item I is not disclosed

Other independent variables are Corporate Governance as measured by:

1) The size of the board of commissioners

2) The size of the board of directors

3) Size of the audit committee

2. Dependent variable is the type of variable that is explained or influenced by the independent variable, the dependent variable is also suspected as a result of the existence of an independent variable (presumed effect variable). The dependent variable used is the company performance which is measured using ROA.

$$
R O A=\frac{E A T}{\text { Total Assets }}
$$

\section{Sample}

This study uses quantity data samples obtained from the IDX website www.idx.co.id and the company's website where the data are examined using purposive sampling method, in the form of sampling with criteria in accordance with certain considerations. The selection of samples of annual financial report data is only from State Owned Companies that are registered in the Indonesia Stock Exchange in the 2012-2017 period. The number of samples in this study was 14 companies.

\section{Analysis Data Method Determination of data model}

Determination of the model aims to determine whether the test is suitable with the existing data model. There are 3 panel data test models conducted before performing regression analysis, namely chow test, langrange multiplier test 
and hausman test and the test results are then used to determine the use of analytical methods, namely Random Effect, Common Effect or Fixed Effect. To determine the right model, the following tests are carried out:

\section{Chow Test}

Chow Test is a test to determine whether fixed effect model or PLS is more precise to use in statistic research model. The hypothesis in the chow test is as follows:

H_0 : Using Common Effect (CE) model

H_1 : Using Fixed Effect (FE) model

The test is done by seeing the probability value F-stat, if the value of F-stat prob is smaller than alpha so the the research model is more precise using FE model.

2. Lagrange Multiplier Test

Lagrange Multiplier (LM) Test is a test which is done to determine whether RE model or PLS is more precise to use. Hypothesis in LM test as follows:

H_0 : Using PLS model

H_1 : Using Random Effect (RE) model

To determine which hypothesis that is accepted, so it is seen by probability value of chi-square. If chi-square prob value is smaller than alpha so regression model is precise using RE model.

\section{Hausman Test}

Hausman Test is a test which is done to determine whether FE model or RE is more precise to use. Hypothesis in Hausman Test as follows:

H_0 : Using RE model

H_1 : Using FE model

To determine which hypothesis which is accepted, it can be seen from $F$-stat probability value, if value of $F$-stat prob is smaller than alpha so the regression model is more precise to use FE model.

\section{Analysis of Multiple Linear Regression}

Multiple linear regression analysis is testing a linear relationship between two or more independent variables with the dependent variable. This analysis is conducted to determine the direction of the relationship between the independent variable and the dependent variable, whether each independent variable is positively or negatively related. the data analysis method used to measure the influence of corporate social responsibility and corporate governance on company's performance is statistical analysis in the form of testing hypothesis using statistical tests. The statistical analysis used in this study is a multiple linear regression equation which is formulated as follows.

$R O A_{i t}=\alpha+\beta_{1} C S R_{i t}+\beta_{2} G C G_{i t}+\varepsilon_{i t}$

Notes: $i$ : Number of Company

$t$ : Periode of 2012-2017

ROA: Return on Assets

CSR: Corporate Social Responsibility

GCG: Good Corporate Governance

$\varepsilon_{i t}$ : Error Term

\section{Determination Coefficient ( $R^{2}$ Test)}

The test of the coefficient of determination is a test to find out how much the variation of the value of the dependent variable can be explained by the variation of the values of the independent variables. $R^{2}$ values will show how much X will affect the movement of Y. The bigger of the $R^{2}$ results is better because this shows that the better the independent variable will explain the dependent variable.

\section{Partial Regression Coefficient Test ( $t$ test)}

Statistical test $t$ basically shows how far the influence of an explanatory/independent variable individually in explaining the variation of the dependent variable (Yusoff et al., 2016). Partial testing of the independent variables used in this study are:

a. If the tcount obtained from the processing value is bigger than $t$ table, it can be concluded that there is a partial effect between the independent variable and the dependent variable.

b. If the tcount obtained from the processing value is smaller than t table, it can be concluded that there is no partial effect between the independent variable and the dependent variable.

\section{Simultaneous Regression Coefficient Test ( $F$ Test)}

$F$ test is used to measure whether all independent variables together have a significant effect on the dependent variable. Simultaneous testing is done by comparing the level of significance of $F$ from the test results with the significance value used in this study. Simultaneous testing of the independent variables used in this study are:

a. If the calculation obtained from the processing value is bigger than Ftable, it can be concluded that there is a simul- 
taneous influence between all independent variables with the dependent variable.

b. If the calculation obtained from the processing value is smaller than the $F$ table value, it can be concluded that there is no simultaneous effect between all independent variables with the dependent variable.

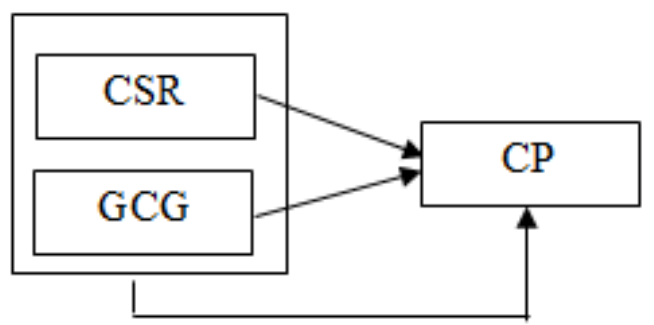

FIGURE 2. The model of the effect of CSR, GCG, on company's performance

\section{RESULTS}

Data Analysis

\section{Determination of Data Model}

Determination of the model aims to determine whether the test is suitable with the existing data model. There are 3 panel data test models conducted before performing regression analysis, namely chow test and hausman test and the test results are then used to determine the use of analytical methods, namely Random Effect, Common Effect or Fixed
Effect.

\section{Chow test}

Chow Test is used to determine whether the research model is more suitable to use Common Effect (CE) method or Fixed Effect (FE) method. The following below presents a table of the results of the chow tests that have been carried out. Based on the results of the Chow test, shows the value of the Chi-square Cross-section probability of 0.0000 is smaller than 0.05 , then a better model is a Fixed Effect.

TABLE 1. The result of chow tests

\begin{tabular}{llll}
\hline \hline Effects Test & Statistic & d.f. & Prob. \\
\hline Redundant Fixed Effects Tests & & & \\
& & & \\
Equation: Untitled Test cross-section fixed effects & & & \\
Cross-section $F$ & 10.277652 & $(13,66)$ & 0.0000 \\
Cross-section Chi-square & 92.963482 & 13 & 0.0000 \\
\hline \hline
\end{tabular}

\section{Hausman test}

Hausman test is used to determine whether the research method is more precise using FE method or RE method. Based on the results of the Hausman test, shows the Chi- square Cross-section probability value of 0.0464 is smaller than 0.05 , then the better model is Fixed Effect. Thus, in this study the regression model that used is the Fixed Effect model.

TABLE 2. The result of hausman tests

\begin{tabular}{llcc}
\hline \hline Test Summary & Chi-Sq. Statistic & Chi-Sq. d.f. & Prob. \\
\hline Correlated Random Effects - Hausman Test & & & \\
Equation: Untitled & & & \\
Test cross-section random effects & & & \\
Cross-section random & 9.666822 & 4 & 0.0464 \\
\hline \hline
\end{tabular}

\section{Analysis of Multiple Linear Regression}

The following is the presentation and results of multiple linear regression analysis.

Based on the results of the analysis above, so it can be made the multiple regression equations which are formulated as follows:

$$
\begin{aligned}
& \mathrm{ROA}=\mathrm{C}(1)+\mathrm{C}(2)^{*} \mathrm{CSR}+\mathrm{C}(3)^{*} \mathrm{GCG}_{-} \mathrm{DD}+ \\
& \mathrm{C}(4)^{*} \mathrm{GCG}+\mathrm{C}(5) * \mathrm{GCG}{ }_{-} \mathrm{KA}+[\mathrm{CX}=\mathrm{F}] \\
& \mathrm{ROA}=19.86983-20.62858^{*} \mathrm{CSR}+0.413354^{*} \mathrm{GCG} \mathrm{DD}- \\
& 0.99576^{*} \mathrm{GCG}_{-} \mathrm{DK}+0.968309^{*} \mathrm{GCG}_{-} \mathrm{KA}+[\mathrm{CX}=\mathrm{F}]
\end{aligned}
$$


TABLE 3. The result of multiple linier regression

\begin{tabular}{lllll}
\hline \hline Variable & Coefficient & Std. Error & $t$-Statistic & Prob. \\
\hline C & 19.86983 & 10.85498 & 1.830481 & 0.0717 \\
CSR & -20.62858 & 9.896281 & -2.084478 & 0.0410 \\
GCG_DD & 0.413354 & 1.077130 & 0.383755 & 0.7024 \\
GCG_DK & -0.995760 & 1.092979 & -0.911051 & 0.3656 \\
GCG_KA & 0.968309 & 0.868319 & 1.115153 & 0.2688 \\
\hline \hline
\end{tabular}

The interpretation of the equation of the multiple linear regression model above is as follows:

\section{Constants}

The constant is 19.86983 , it means that if all the independent variables and intervening variables, namely CSR and GCG, are equal to 0 (zero), then the ROA is positive at 19.86983.

2. CSR Regression Coefficient

CSR regression coefficient is negative at 20.62858. This illustrates that every increase in Rp1 CSR, the ROA of the company will decrease by 20.62858 , with the assumption the other influenced variable is remaining.

3. Regression Coefficient of the Board of Directors

Board of Directors Regression Coefficient has a positive value of 0.413354 which illustrates that for every 1 Board of Directors increase, ROA will increase by 0.413354 with the assumption the other influenced variable is remaining.
4. Board of Commissioners Regression Coefficient

The Board of Commissioners' Regression Coefficient has a negative value of 0.99576 , this illustrates that every increase of 1 Board of Commissioners, ROA will decrease by 0.99576 with the assumption the other influenced variable is remaining.

5. Audit Committee Regression Coefficient

Audit Committee Regression Coefficient has a positive value of 0.968309 this illustrates that every increase of 1 Audit Committee then ROA will increase by 0.968309 with the assumption the other influenced variable is remaining.

\section{Determination Coefficient Test $\left(R^{2}\right)$}

Test of determination or accuracy of the googness of fit model to measure the size of the model's ability to explain the dependent variable. The small values of $R^{2}$ means the ability of independent variables in explaining dependent variables are very limited.

TABLE 4. The result of determination coefficient test

\begin{tabular}{llll}
\hline \hline$R$-squared & 0.733874 & Mean dependent var & 5.555595 \\
Adjusted R-squared & 0.665326 & S.D. dependent var & 7.227470 \\
S.E. of regression & 4.181164 & Akaike info criterion & 5.886466 \\
Sum squared resid & 1153.821 & Schwarz criterion & 6.407355 \\
Log likelihood & -229.2316 & Hannan-Quinn criter. & 6.095859 \\
$F$-statistic & 10.70603 & Durbin-Watson stat & 1.260408 \\
Prob $(F$-statistic $)$ & 0.000000 & & \\
\hline \hline
\end{tabular}

Based on the results presented in the table, the $R$-squared value is 0.733874 or $73.39 \%$. This shows that CSR independent variables and GCG are able to explain the dependent variable ROA of 0.733874 or $73.39 \%$, while the remaining $26.61 \%$ is explained by other variables outside the research.

\section{Partial Regression Coefficient Test ( $t$ test)}

The test that used to test the independent variable is a partial test ( $t$ test). This test aims to determine the effect of independent variables on the research model. Referring to the table resulting from multiple linear regression analysis, the CSR variable has a probability value of 0.0410 . If the probability is $<0.05$ then $\mathrm{H} 1$ is accepted, and if the probability is $>0.05$ then $\mathrm{H} 1$ is rejected. Based on this, the prob- ability value is less than $0.05(0.0410<0.05)$ so $\mathrm{H} 1$ is accepted. Thus it can be concluded that the existence of CSR disclosures has a significant negative effect on ROA in State Owned Enterprises that registered on the IDX.

Referring to the table resulting from multiple linear regression analysis, variable of Board of Directors has a probability value of 0.7024 . If the probability is $<0.05$ then $\mathrm{H} 1$ is accepted, and if the probability is $>0.05$ then $\mathrm{H} 1$ is rejected. Based on this, the probability value is bigger than $0.05(0.7024>0.05)$ then $\mathrm{H} 1$ is rejected. Thus, it can be concluded that the Board of Directors has no significant effect on ROA on State Owned Enterprises that registered on the IDX. Referring to the table resulting from multiple linear regression analysis, the Board of Commissioners vari- 
able has a probability value of 0.3656 . If the probability is $<0.05$ then $\mathrm{H} 1$ is accepted, and if the probability is $>0.05$ then $\mathrm{H} 1$ is rejected. Based on this, the probability value is bigger than $0.05(0.3656>0.05)$ then $\mathrm{H} 1$ is rejected. Thus it can be concluded that the Board of Commissioners has no significant effect on ROA on State Owned Enterprises that registered on the IDX.

Referring to the table resulting from multiple linear regression analysis, the Audit Committee variable has a probability value of 0.2688 . If the probability is $<0.05$ then $\mathrm{H} 1$ is accepted, and if the probability is $>0.05$ then $\mathrm{H} 1$ is rejected. Based on this, the probability value is bigger than $0.05(0.2688>0.05)$ then $\mathrm{H} 1$ is rejected. Thus it can be concluded that the Audit Committee has no significant effect on ROA on State Owned Enterprises that registered on the IDX.

\section{Simultaneous Regression Coefficient Test ( $F$ Test)}

Based on the table on the coefficient of determination $\left(R^{2}\right)$, the probability value ( $F$-statistic) is 0.0000 . If the probability is $<0.05$ then $\mathrm{H} 1$ is accepted, and if the probability is > 0.05 then $\mathrm{H} 1$ is rejected. Based on this, the probability value is smaller than $0.05(0.0000>0.05)$ then $\mathrm{H} 1$ is accepted. Thus it can be concluded that CSR, the Board of Directors, the Board of Commissioners, and the Audit Committee have a significant effect on ROA on State Owned Enterprises that registered on the IDX.

\section{DISCUSSION}

\section{Effect of CSR on ROA}

Based on the results in the previous table, it was found that CSR had a significant effect on ROA. This illustrates the CSR carried out by State Owned Enterprises registered on the Stock Exchange having an influence on the company performance. The implementation of CSR creates good performance for the company. Good company performance will be more attractive to investors because the better the performance of the company, the higher the consumer loyalty. As consumer loyalty increases, it is expected that the level of profitability of the company will increase and will increase the value of the company.

Some things that can cause CSR affect the company's performance, there are:

1. Information on corporate social responsibility has been responded well by investors.

2. The company has communicated the CSR message appropriately so that the meaning of CSR can be well received by other interested parties.

3. Management realizes the importance of CSR as a longterm social investment.
4. Management understands that corporate responsibility is not only for shareholders but also other interested parties.

\section{GCG Effect on ROA}

The results of the study shows that good GCG with the indicators of the Board of Directors, Board of Commissioners, and Audit Committee had no significant effect on ROA. This illustrates that although the three GCG indicators are part of the interconnected elements of corporate governance that come from within the company and are also a mechanism for GCG, it seems that the GCG mechanism has not been well implemented by State Owned Enterprises that registered on the Indonesia Stock Exchange. The company does not pay attention to the control aspects that should be carried out for future company development and corporate value creation.

This requires an increase in supervision for the company towards a better direction. Having good implementation of GCG in the company, by selecting a competent board of commissioners who will oversee the performance of the board of directors in carrying out the company's policies and strategies, the board of directors will be better at performing its performance to improve its performance. Likewise with the existence of a board of directors who are competent in conducting company strategic planning. Likewise, the audit committee has a very important role in helping the board of commissioners to oversee internal control in the company so that a conducive working environment will be created and the company will be well managed which it will increase the company's ROA.

\section{Effect of CSR and GCG on ROA}

Based on the results of this study, CSR and GCG variables with the size of the board of commissioners, the size of the board of directors, and the size of the audit committee simultaneously (together) have a significant effect on ROA. This illustrates that if the CSR carried out by State Owned Enterprises that registered on the IDX is carried out together with the implementation of a good corporate governance mechanism, both will affect the company's performance.

\section{CONCLUSION}

1. Based on the results of the study, it is concluded that CSR had an effect on ROA. The implementation of CSR creates good performance for the company. Good company performance will be more attractive to investors and it is expected that the level of profitability of the company will increase. 2. Based on the results of the study, it is concluded that GCG 
did not affect ROA. This illustrates the mechanism of GCG has not been done well by State Owned Enterprises that registered on the Indonesia Stock Exchange.

3. It is concluded that CSR, the Board of Directors, the Board of Commissioners, and the Audit Committee have a significant effect on ROA in State Owned Enterprises that registered on the IDX.

\section{IMPLICATIONS}

1. The company should continue to disclose social information in order to improve the positive image (brand), and help in sustainable development.

2. Implementation of GCG is very necessary to build public trust in value creation. Therefore, companies need to implement GCG principles and practices in each company unit.

3 . The next researcher is expected to be able to multiply the research variables, for example other measures of good corporate governance, measurement of other corporate social responsibility, as well as measures of company performance such as liquidity, leverage, market performance, and others.

\section{REFERENCES}

Andriana, A., \& Panggabean, R. R. (2016). The effect of good corporate governance and environmental performance on financial performance of the proper listed company on Indonesia stock exchange. Business Review, 8(1), 1-12. doi: https://doi.org/10.21512/bbr.v8i1.1757

Aslam, S., Ahmad, M., Amin, S., Usman, M., \& Arif, S. (2018). The impact of corporate governance and intellectual capital on firm's performance and corporate social responsibility disclosure. Pakistan Journal of Commerce and Social Sciences, 12(1), 283-308.

Basyith, A. (2016). Corporate governance, intellectual capital and firm performance. Research in Applied Economics, 8(1), 17-41. doi:https://doi.org/10.5296/rae.v8i1.8675

Baysinger, B. D., \& Butler, H. N. (1985). Corporate governance and the board of directors: Performance effects of changes in board composition. Journal of Law, Economics, \& Organization, 1(1), 101-124. doi:https://doi.org/10.1093/ oxfordjournals.jleo.a036883

Bhardwaj, P., Chatterjee, P., Demir, K. D., \& Turut, O. (2018). When and how is corporate social responsibility profitable? Journal of Business Research, 84, 206-219. doi:https://doi.org/10.1016/j.jbusres.2017.11.026

Borhan, H., Naina Mohamed, R., \& Azmi, N. (2014). The impact of financial ratios on the financial performance of a chemical company: The case of lyondell basell industries. World Journal of Entrepreneurship, Management and Sustainable Development, 10(2), 154-160. doi:https://doi.org/10.1108/wjemsd-07-2013-0041

Brickley, J. A., \& Zimmerman, J. L. (2010). Corporate governance myths: Comments on armstrong, guay, and weber. Journal of Accounting and Economics, 50(2-3), 235-245. doi:https://doi.org/10.1016/j.jacceco.2010.10.002

Carroll, A. B. (1979). A three-dimensional conceptual model of corporate performance. Academy of Management Review, 4(4), 497-505. doi:https://doi.org/10.5465/AMR.1979.4498296

Carroll, A. B. (1991). Sprinkle and maines. Business Horizons, 34(5), 39-48. doi:https://doi.org/10.1177/ 0312896211432941

Chakravarthy, B. S. (1986). Measuring strategic performance. Strategic Management Journal, 7(5), 437-458. doi:https:// doi.org/10.1002/smj.4250070505

Cho, H.-J., \& Pucik, V. (2005). Relationship between innovativeness, quality, growth, profitability, and market value. Strategic Management Journal, 26(6), 555-575. doi:https://doi.org/10.1002/smj.461

Ciftci, I., Tatoglu, E., Wood, G., Demirbag, M., \& Zaim, S. (2019). Corporate governance and firm performance in emerging markets: Evidence from Turkey. International Business Review, 28(1), 90-103. doi:https://doi.org/10.1016/j.ibusrev .2018.08.004

Clark, D., \& Sanders, J. (2011). Beginning c\# object-oriented programming. New York, NY: Springer.

Dewanta, D. . (2011). Pengaruh mekanisme corporate governance terhadap pengungkapan tanggung jawab sosial pada perusahaan ilq 45 yang terdaftar di bursa efek Indonesia (Unpublished master thesis). Tinggi Ilmu Ekonomi Indonesia (STIESIA), Surabaya, Indonesia.

Drucker, E. (1997). The organization of the future. New York, NY: Sage Publications.

Effendi, S. (2009). Citadel of faith. California, CA: International Business Publications. 
Elkington, J. (1998). Partnerships from cannibals with forks: The triple bottom line of 21st-century business. Environmental Quality Management, 8(1), 37-51. doi:https://doi.org/10.1002/tqem.3310080106

Global Reporting Initiative. (2013). 2013 global conference on sustainability and reporting conference in review. Retrieved from https://urlzs.com/snhNv (accessed on 14 July, 2018)

Gray, R., Owen, D., \& Maunders, K. (1988). Corporate social reporting: Emerging trends in accountability and the social contract. Accounting, Auditing \& Accountability Journal, 1(1), 6-20. doi:https://doi.org/10.1108/eum0000000004617

Hadi, N. (2011). Corporate social responsibility. Yogyakarta, Indonesia: Graha Ilmu.

Hang, H. T. T. (2015). The effect of capital structure on corporate performance: Evidence in Vietnam. International Journal of Business and Administrative Studies, 1(2), 68-77. doi:https://doi.org/10.20469/ijbas.10005-2

Hema, D. (2012). Financial reporting and corporate governance: An empirical study. International Journal of Multidisciplinary Research, 2(2), 45-56.

Herdjiono, I., \& Sari, I. M. (2017). The effect of corporate governance on the performance of a company: Some empirical findings from Indonesia. Journal of Management and Business Administration, 25(1), 33-52. doi:https://doi.org/ 10.7206/jmba.ce.2450-7814.188

Hou, T. C.-T. (2019). The relationship between corporate social responsibility and sustainable financial performance: Firm-level evidence from Taiwan. Corporate Social Responsibility and Environmental Management, 26(1), 19-28. doi:https://doi.org/10.1002/csr.1647

Jensen, M. C., \& Meckling, W. H. (1976). Theory of the firm: Managerial behavior, agency costs and ownership structure. Journal of Financial Economics, 3(4), 305-360. doi:https://doi.org/10.1016/0304-405x(76)90026-x

Karwowski, M. (2014). Sprzeniemierzanie kreatywnosci? Retrieved from https://urlzs.com/RX4xv (accessed on 14 June, 2018)

Ketsiri, K., \& Pajongwong, P. (2016). Knowledge and understanding of accountants toward rules for calculating net income for corporate income tax by section 65 ter in Thailand. International Journal of Business and Economic Affairs, 1(1), 67-73. doi:https://doi.org/10.24088/ijbea-2016-11009

Kiel, G. C., \& Nicholson, G. J. (2003). Board composition and corporate performance: How the Australian experience informs contrasting theories of corporate governance. Corporate Governance: An International Review, 11(3), 189-205. doi: https://doi.org/10.1111/1467-8683.00318

Kotler, P., \& Lee, N. (2008). Corporate social responsibility: Doing the most good for your company and your cause. New York, NY: John Wiley \& Sons.

Makki, M. A. M., \& Lodhi, S. A. (2014). Impact of corporate governance on intellectual capital efficiency and financial performance. Pakistan Journal of Commerce and Social Sciences, 8(2), 305-330.

Marfa, M. A., Niguidula, J. D., \& Enriquez, J. B. (2017). Business analytics in performance assessment of food manufacturing system. International Journal of Business and Economic Affairs, 2(2), 159-164. doi:https://doi.org/10.24088/ijbea -2017-22009

Menaje Jr, P. M. (2012). Impact of selected accounting and economic variables on share price of publicly listed banks in the Philippines from 2002-2008. Business \& Economics Review, 22(1), 35-62.

O'Rouke, T. (2004). Malting of barley. Journal of the Institute of Brewing, 109, 21-23. doi:https://doi.org/10.1002/j.2050 -0416.1923.tb06604.x

Priantana, R. D., \& Yustian, A. (2011). Pengaruh struktur good corporate governance terhadap pengungkapan corporate social responsibility pada perusahaan keuangan yang terdaftar di bursa efek Indonesia. Jurnal Telaah dan Riset Akuntansi, 4(1), 65-78.

Purnamasari, K., \& Fitdiarini, N. (2016). Corporate diversification and cash holding. Journal of Administrative and Business Studies, 1(1), 21-27. doi:https://doi.org/10.20474/jabs-1.1.4

Ratih, S., \& Setyarini, Y. (2014). Pengaruh Good Corporate Governance (GCG) Dan Corporate Social Responsibility (CSR) terhadap nilai perusahaan dengan kinerja keuangan sebagai variable intervening pada perusahaan pertambangan yang go public di bei. Jurnal Akuntansi, 5(2), 115-132. doi:https://doi.org/10.26740/jaj.v5n2.p115-132

Reverte, C. (2009). Determinants of corporate social responsibility disclosure ratings by Spanish listed firms. Journal of Business Ethics, 88(2), 351-366. doi:https://doi.org/10.1007/s10551-008-9968-9 
Ridho, T. K. (2016). The influence of CSR on performance and its determinants in listed companies in Indonesia. Actual Problems of Economics, 184(10), 259-268. doi:https://doi.org/10.1111/auar.12090

Sari, R. A. (2012). Pengaruh karakteristik perusahaan terhadap corporate social responsibility disclosure pada perusahaan manufaktur yang terdaftar di bursa efek Indonesia. Nominal, Barometer Riset Akuntansi dan Manajemen, 1(2), 23-30. doi:https://doi.org/10.21831/nominal.v1i2.1002

Sun, L. (2012). Further evidence on the association between corporate social responsibility and financial performance. International Journal of Law and Management, 54(6), 472-484. doi:https://doi.org/10.1108/17542431211281954

Wartika, K., Surendro, H., Satramihardja, I., \& Supriana. (2015). Business process improvement conceptual models to improve the efficiency of power consumption on computer use from the perspective of human resource performance. International Journal of Business and Administrative Studies, 1(3), 99-106. doi:https://doi.org/10.20469/ijbas.10004-3

World Bank. (2017). Indonesia Public Expenditure and Financial Accountability (PEFA). (accessed on 15 June, 2017) doi: https://urlzs.com/VNMTY

Yoo, J., Lee, M. K., \& Lee, W. S. (2016). Asymmetrical corporate responses to economic information: Applying the firm size effect. Journal of Administrative and Business Studies, 2(1), 29-34. doi:https://doi.org/10.20474/jabs-2.1.4

Yusoff, H., Jamal, A. D. A., \& Darus, F. (2016). Corporate governance and corporate social responsibility disclosures: An emphasis on the CSR key dimensions. Journal of Accounting and Auditing: Research and Practice, 3(5), 1-14. doi: https://doi.org/10.5171/2016.476550 